\title{
PEMBERIAN POC DENGAN RENTANG WAKTU BERBEDA TERHADAP KELIMPAHAN Chlorella sp
}

\section{Provision of POC with Different Time of Abundance Chorella sp.}

\author{
Rosyadi, Agusnimar, Hisra Melati \\ Program Studi Budidaya Perairan, Jurusan Perikanan \\ Fakultas Pertanian, Universitas Islam Riau \\ Email: rosyadi@agr.uir.ac.id \\ [Diterima: Oktober 2019; Disetujui: November 2019]
}

\begin{abstract}
This study aims to determine the effect of giving POC with different time ranges on abundance. The study was carried out for 18 days in the Microalgae Laboratory of the Fish Seed Institute of the Faculty of Agriculture, Riau Islamic University, Pekanbaru. The method used is a completely randomized design (CRD) with 5 treatments 3 replications, namely: $\mathrm{P} 1$ giving $\mathrm{POC}$ on day 5, P2 giving POC on day 6, P3 giving POC on day 7, P4 giving POC on day -8 and P5 administration of POC on the $9^{\text {th }}$ day. From the results of the study, the highest density of Chlorella sp was found on P3 treatment with a total density of $9,833,333 \mathrm{cells} / \mathrm{ml}$ on the $5^{\text {th }}$ day. The lowest average peak was in the treatment of $\mathrm{P} 1$ with $2,566,667$ cells/ml on the ${ }^{12 \text { th }}$ day. Water quality such as temperature ranged from 25 to $30^{\circ} \mathrm{C}$ and $\mathrm{pH}$ between 6.5-7.
\end{abstract}

Keywords: Chorella sp, POC, Population Abundance

\begin{abstract}
ABSTRAK
Penelitian ini bertujuan untuk mengetahui pengaruh pemberian poc dengan rentang waktu berbeda terhadap kelimpahan. Penelitian dilaksanakan selama 18 hari di Laboratorium Mikroalga Balai Benih Ikan Fakultas Pertanian Universitas Islam Riau Pekanbaru. Metode yang digunakan adalah rancangan acak lengkap (RAL) dengan 5 perlakuan 3 ulangan yaitu : P1 pemberian POC pada hari ke -5, P2 pemberian POC pada hari ke -6, P3 pemberian POC pada hari ke -7, $\mathrm{P} 4$ pemberian POC pada hari ke -8 dan P5 pemberian POC pada hari ke -9 Dari hasil penelitian kepadatan Chlorella sp tertinggi pada perlakuan $\mathrm{P} 3$ dengan jumlah kepadatan $9.833 .333 \mathrm{sel} / \mathrm{ml}$ pada hari ke- 5 . Puncak ratarata terendah pada perlakuan P1 dengan jumlah sel $2.566 .667 \mathrm{sel} / \mathrm{ml}$ pada hari ke 12 . Kualitas air seperti suhu berkisar 25-30 ${ }^{\circ} \mathrm{C}, \mathrm{pH}$ 6,5-7.
\end{abstract}

Kata Kunci: Chorella sp, POC, Kelimpahan Populasi

\section{PENDAHULUAN}

Ketersedian pakan akan berpengaruh besar terhadap kelangsungan hidup dan pertumbuhan ikan. Jumlah pakan yang dibutuhkan oleh ikan setiap harinya berhubungan erat dengan ukuran berat dan umur ikan (Djarijah, 1995). Ketersediaan pakan alami di suatu perairan harus dalam jumlah yang memadai tepat waktu dan berkesinambungan. Masalah klasik yang sering dihadapi oleh pembudidaya ikan atau udang adalah tingginya tingkat kematian larva.

Larva udang atau ikan harus mendapatkan makanan dari luar, karena pada stadia ini kuning telur yang dibawa dari lahir habis, sehingga suplai pakan dari luar adalah faktor penting dalam usaha pemeliharaan larva udang selanjutnya. Hampir sebagian besar pembenihan yang ada di Indonesia melakukan kultur untuk penyediaan pakan alami dari jenis Chlorella sp (Cahyo, 2011). Chlorella sp sebagai pakan alami larva/benih ikan memiliki beberapa keuntungan, seperti mudah dibudidayakan, ukuran yang relatif sesuai dengan ukuran bukaan mulut ikan, kemampuan berkembangbiak dengan cepat dalam waktu yang relatif singkat, sehingga ketersediaannya dapat terjamin sepanjang waktu dan biaya yang relatif murah (Siregar, 2010).

Salah satu nutrien yang digunakan untuk menumbuhkan Chlorella sp berupa air lindi hasil pengomposan sampah sayuran, yang berasal dari limbah pasar. Kandungan senyawa dalam limbah akan terdekomposisi menjadi 
senyawa anorganik seperti nitrat dan fosfat yang dapat direduksi dengan memanfaatkan Chlorella sp. Hal ini membuat Pupuk Organik Cair diduga cocok untuk media pertumbuhan mikroalga jenis Chlorella sp. Sebagai dosis awal penggunaan pupuk organik cair pada penelitian ini merujuk dari penelitian yang dilakukan Nur (2018) yakni sebesar $5 \mathrm{ml} / \mathrm{L}$ media kultur.

Untuk menjaga keberlanjutan kelimpahan Chlorella sp, perlu dicari rentang waktu pemberian pupuk organik cair yang sesuai untuk menumbuhkan Chlorella sp. Oleh karena itu penulis tertarik melakukan

Tabel 1. Alat-alat Penelitian pemberikan POC dengan rentang waktu berbeda terhadap kelimpahan Chlorella sp.

\section{METODE PENELITIAN}

\section{Bahan dan Alat}

Bahan yang digunakan pada penelitian ini antara lain adalah chlorella sp yang digunakan sebagai inokulan dalam kultur pakan alami, Pupuk Organik Cair (POC) yang berasal dari Jalan. Cempaka sebagai unsur hara untuk kelimpahan Chlorella sp. Sedangkan alat yang digunakan pada penelitian ini adalah:

\begin{tabular}{clrl}
\hline No & \multicolumn{1}{c}{ Nama Alat } & Jumlah & \multicolumn{1}{c}{ Keterangan } \\
\hline 1 & Galon & 15 buah & Wadah penelitian \\
2 & Ijuk, pasir, kerikel dan arang & 1 unit & Bahan saringan media tumbuh \\
3 & Selang Aerasi & 15 buah & Penghubung antara blower dan batu aerasi \\
4 & Batu Aerasi & 15 buah & Mengatur besar kecilnya gelembung udara \\
5 & Thermometer & 1 buah & Mengukur suhu air \\
6 & Haemocytometer & 2 buah & Wadah menghitung kepadatan Chlorella sp \\
7 & Micro pipet & 2 buah & Mengambil air sampel \\
8 & Breaker Glass & 1 buah & wadah air sampel \\
9 & Cawan Petri & 2 buah & Wadah air sampel \\
10 & Handycounter & 1 buah & Menghitung sel Chlorella sp \\
11 & pH meter & 1 kotak & Mengukur keasaman air \\
12 & Lampu neon & 6 buah & Pencahayaan Media Kultur \\
13 & Gelas Ukur & 2 buah & Mengukur takaran \\
14 & Blower & 1 buah & Sumber oksigen \\
15 & Mikroskop elektrik & 1 buah & Mengamati plankton \\
16 & Komputer & 1 unit & Menghitung Chlorella sp \\
17 & Camera & 1 buah & Dokumentasi penelitian \\
\hline
\end{tabular}

\section{Persiapan Pupuk Organik Cair (POC)}

Membersihkan dan menjemur bahanbahan penyaring (filter) untuk mendapatkan pupuk yang steril dari bakteri. Mengisi drum dengan bahan-bahan penyaring dengan urutan yang telah ditentukan dan masukkan pupuk organik cair ke dalam drum penyaring tersebut. Dari hasil saringan tersebut, kemudian pupuk organik cair direbus hingga mendidih agar bakteri dan mikroorganisme yang dapat menganggu selama penelitian mati.

Setelah direbus, pupuk organik organik cair tersebut didinginkan, selanjutnya di masukkan dalam jeregen dan didiamkan selama satu hari. Setelah itu pupuk organik cair siap digunakan untuk kultur Chlorella sp. Jumlah pupuk organik cair yang digunakan pada awal penelitian, sebanyak $5 \mathrm{ml} / \mathrm{L}$ media kultur. Selanjutnya dilakukan pemupukan susulan dengan rentang waktu 4 hari, dengan jumlah pupuk organik cair sebanyak $1,5 \mathrm{ml} / \mathrm{L}$ media kultur. Penelitian dilakukan selama 30 hari pengamatan, dengan mengukur hari puncak populasi dan kelimpahan serta jumlah biomassa Chlorella sp.

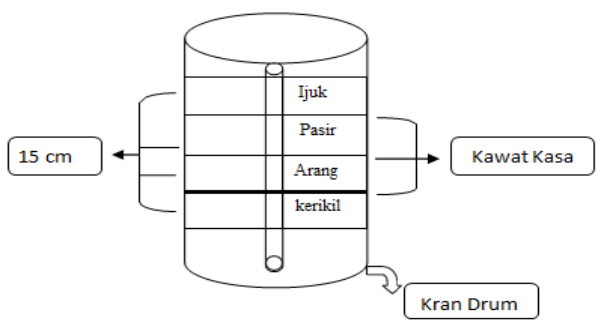

Gambar 1. Model Saringan

\section{Persiapan Wadah}

Mempersiapkan bahan dan alat, diantaranya membuat rak kultur, membersihkan alat-alat agar steril, sehingga tidak terkontaminasi oleh organisme yang merugikan. Wadah yang digunakan dalam penelitian ini berupa, botol galon dengan volume gallonnya 6 liter sebanyak 15 buah. 


$$
\begin{gathered}
\text { Jumlah Sel }= \\
(\mathrm{A} 1+\mathrm{A} 2+\mathrm{A} 3+\mathrm{A} 4+\mathrm{A} 5) / 80 \times 400 \times 10.000
\end{gathered}
$$

Sedangkan untuk mengkultur Chlorella $\mathrm{sp}$ digunakan media kultur sebanyak 5 liter.

\section{Kultur Chorella sp}

Setelah pupuk dimasukkan ke dalam wadah kultur, selanjutnya didiamkan atau diendapkan selama 3 hari. Setelah itu dilanjutkan dengan penebaran bibit Chlorella sp yang telah dikultur sebelumnya dan selanjutnya dimasukan ke dalam setiap galon atau wadah kultur, dengan kepadatan awal sebanyak $50 \times 10^{4}$ sel/L air media kultur. Penghitungan kepadatan Chlorella sp dilakukan setiap dua hari sekali, menggunakan mikroskop elektrik yang dilengkapi dengan perangkat komputer.

\section{Rancangan Percobaan}

Rancangan percobaan dalam penelitian ini menggunakan Rancangan Acak Lengkap (RAL) dengan 5 perlakuan dan 3 ulangan. Adapun perlakuan yang digunakan sebagai berikut:

P1 = Pemberian Pupuk Organik Cair pada hari ke-5

P2 = Pemberian Pupuk Organik Cair pada hari ke-6

P3 = Pemberian Pupuk Organik Cair pada hari ke-7

P4 = Pemberian Pupuk Organik Cair pada hari ke-8

P5 = Pemberian Pupuk Organik Cair pada hari ke-9

\section{Perhitungan Kelimpahan Sel Chlorella sp}

Menghitung kelimpahan sel Chlorella $s p$ pada setiap tahap penelitian dilakukan dengan Haemocytometer Neubawer Improved (Isnansetyo dan Kurniastuty, 1995).

1. Kepadatan Rendah

Keterangan :

A : Jumlah sel dalam chamber

\begin{tabular}{|ll|}
\hline & \multicolumn{1}{c|}{ Jumlah $\mathrm{Sel}=$} \\
& $(\mathrm{A} 1+\mathrm{A} 2+\mathrm{A} 3+\mathrm{A} 4+\mathrm{A} 5) / 5 \times 25 \times 10.000$ \\
\hline 5 & $:$ Jumlah pengamatan data \\
25 & : Jumlah chamber besar \\
10.000 & : Volume kepadatan chamber
\end{tabular}

2. Kepadatan Tinggi

Keterangan :

A : Jumlah sel dalam chamber

80 : 16 chamber kecil x 5 data

400 : 16 chamber kecil x 25 chmaber besar

10.000 : Volume kepadatan chamber

\section{Perhitungan Biomassa Chlorella sp}

Untuk menghitung biomassa Chlorella sp menggunakan rumus:

$\mathrm{G}=\mathrm{Bx}-\mathrm{Bo}$

Keterangan:

$\mathrm{G}$ = Produktivitas Biomassa $(\mathrm{gr} / \mathrm{L})$

Bo = Berat Awal (gr/L)

$\mathrm{Bx}=$ Berat Akhir $(\mathrm{gr} / \mathrm{L})$

\section{Analisa Data}

Pada penelitian ini yang diamati adalah hari puncak dan pertambahan populasi Chlorella sp. Selain itu, dilakukan pengamatan kualitas air yang diperkirakan berpengaruh terhadap populasi Chlorella sp, seperti suhu, keasaman air dan kandungan oksigen terlarut. Data yang diperoleh disajikan dalam bentuk tabel dan histogram guna memudahkan pengolahan, analisa dan pembahasan dalam menarik kesimpulan.

\section{HASIL DAN PEMBAHASAN}

\section{Laju Kelimpahan sel Chlorella sp}

Grafik pertumbuhan Chlorella sp pada penelitian disajikan pada Gambar 2.

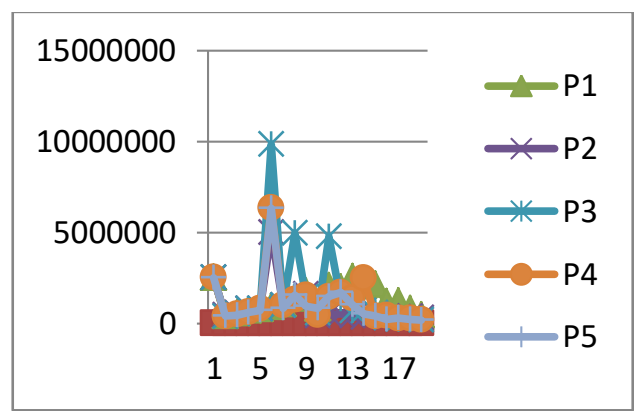

Gambar 2. Kelimpahan Chlorella sp pada Penelitian

Tingginya pertambahan sel Chlorella sp setiap harinya pada P3 disebabkan karena warna media kultur pada P3 terlalu hijau pekat dan jumlah penambahan nutrisi yang yang sangat besar dan hari yang diberikan berbeda sehingga kelimpahan pada Chlorella sp. sangat baik sehingga jumlah dalam media kultur sangat meningkat, sehingga lebih mudah terjadi interaksi positif antara Chlorella sp dengan limbah POC dalam memanfaatkan unsur hara yang ada untuk pertumbuhan selnya melalui proses fotosintesis Chlorella sp. Intensitas cahaya sangat diperlukan dalam 
proses fotosintesis karena hal ini berhubungan dengan jumlah energi yang diterima oleh mikroalga untuk melakukan fotosintesis (Becker, 1994).

Menurut Effendi (2003) bahwa unsur hara pada pupuk digunakan mikroalga sebagai sumber nutrisi bagi pertumbuhannya yang dimana limbah organik tersebut akan diubah menjadi protein. Hasil pengamatan kelimpahan Chorella sp. di atas menunjukan pada hari ke-0 pemberian Chlorella sp. sampai hari ke-14 pertambahan jumlah hasil relatif masih besar, hal ini disebabkan pada pertumbuhannya ini memiliki jumlah unsur hara yang sangat optimal karena pemberian pupuknya sesuai dengan dosis yang diberikan, kemudian berkembang biak sesuai dengan kondisi lingkungan barunya.

Sesuai dengan (Fogg dalam Sidabutar, 2016) sel fitoplankton membutuhkan waktu dan jumlah nutrisi untuk menyesuaikan diri dengan kondisi lingkungan yang baru dan perkembangbiakannya. Setelah mengalami fase pada hari ke-14 sampai hari ke-16 periode ini diperkirakan memasuki fase eksponensial (periode penurunan). Dimana perkembangan sel Chorella sp mengalami penurunan. Peningkatan pertumbuhan sel Chlorella sp disebabkan oleh interaksi positif antara Chlorella sp dengan limbah POC dimana unsur hara yang terdapat dalam media kultur bisa dimanfaatkan semuanya dengan baik oleh Chlorella sp. Sehingga kelimpahan Chlorella sp mengalami puncak dengan jumlah sel yang paling tinggi yang pada dasarnya mengandung nutrient dan pospat yang cukup tinggi.

Selanjutnya pada hari ke-16 sampai hari ke-18 merupakan fase stasioner dimana pertumbuhan Chlorella sp mengalami penurunan dan jumlah sel yang berkembang mulai mati. Dimana pada hari tersebut terjadi penurunan jumlah populasi mikroalga, dikarenakan terbatasnya unsur hara pemberian pupuk tambahan pada wadah penelitian dan juga Chlorella sp tidak mampu hidup lagi dalam media kulturnya, maka terjadi fase penurunan jumlah sel yang berkembang lebih banyak dengan kematianya kelimpahan atau fase kematian Chlorella sp. hingga hari ke-19 (Sidabutar, 2016).

\section{Pertumbuhan Chlorella sp}

Berdasarkan pengamatan grafik pertumbuhan Chlorella sp. diatas puncak pertumbuhan terjadi pada perlakuan P3 sebesar
( 9.833.333), hal ini sesuai dengan penjelasan fase lag (adaptasi) terjadi pada pengamatan ke5 sampai pengamatan ke-14 di mana fase ini masih terjadi penyesuaian terhadap lingkungan. mikroalga Chlorella sp sudah memanfaatkan nutrien untuk pertumbuhan. Secara fisiologis pada fase lag (adaptasi) mikroalga sangat aktif dan terjadi proses sintesis protein baru.

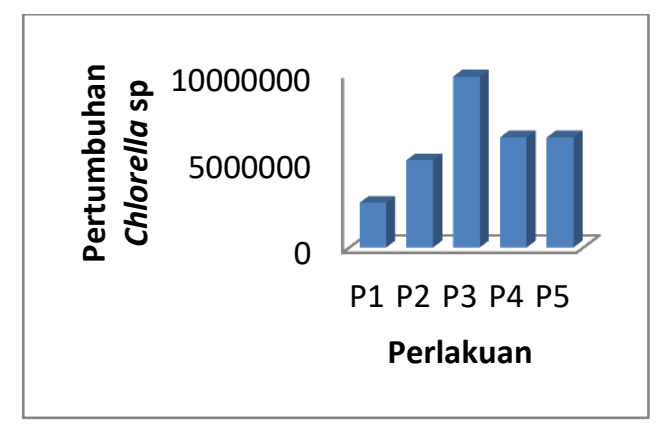

Gambar 3. Pertumbuhan Chlorella sp

Organisme mengalami metabolisme tetapi belum terjadi pembelahan sel secara signifikan sehingga kepadatan sel belum terlalu mengalami peningkatan (Fadilla, 2010). Fase logaritmik (eksponensial) terjadi pada pengamatan ke-5 sampai pengamatan ke- 14 di mana fase ini terjadi peningkatan jumlah sel secara konstan, karena pada awal kultur kandungan nutrien masih tinggi. Nutrien dapat dimanfaatkan oleh masing-masing mikroalga untuk melakukan proses pertumbuhan (Musa $d k k ., 2013)$.

\section{Biomass Chlorella sp}

Pengukuran biomassa mikroalga Chlorella sp. pada penelitian dapat dilihat pada gambar di bawah ini.

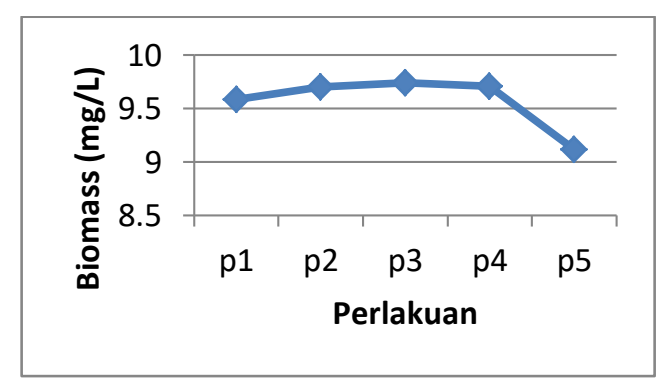

Gambar 4. Pengukuran Biomassa Chlorella sp.

Biomassa mikroalga Chlorella sp selama pengkulturan pada penelitian selama 18 hari. Yang tertinggi pada $\mathrm{P} 3$ yaitu $(9,74 \mathrm{mg} / \mathrm{L})$ dan yang terendah pada $P 5$ yaitu $(9,11 \mathrm{mg} / \mathrm{L})$. Besarnya biomassa pada penelitian ini sebanding dengan kelimpahan sel Chlorella sp. 
semakin melimpah sel mikroalga maka semakin berat biomassa Chlorella sp.

Dalam penelitian, Yolanda dalam Vitriani (2016) memperoleh biomassa terbaik pada konsentrasi limbah dan rentang pemberian pupuk tambahan sebesar $25 \%$ seberat 23,4 $\mathrm{mg} / \mathrm{L}$, hal ini menunjukkan adanya perbedaan yang signifikan antara biomassa yang dihasilkan dari dua jenis limbah cair yang digunakan sebagai media kultur. Menurut Komarawidjaja (2010), pertumbuhan kultur mikroalga sangat dipengaruhi oleh kandungan nutrien unsur hara yang diberikan. Ini dapat dibuktikan melalui ketersediaan unsur hara pada setiap perlakuan yang diberikan pupuk tambahan guna untuk memperoleh kelimpahan dan jumlah biomasa yang tinggi pada $\mathrm{P} 3$.

Namun, pengaruh nutrien terhadap fitoplankton pada kenyataannya tidak diikuti oleh peningkatan kelimpahan dari Chlorella sp. itu sendiri, hal ini dapat disebabkan oleh komposisi unsur hara yang sesuai dengan kebutuhan Chlorella sp.

\section{Kualitas Air \\ Suhu}

Kisaran rata-rata suhu yang diperoleh selama penelitian berkisar antara $29-30{ }^{\circ} \mathrm{C}$, kisaran suhu tersebut merupakan suhu optimal bagi perkembangbiakkan Chlorella sp. Sesuai dengan pendapat Isnansetyo dan Kurniastuty dalam Prabowo (2009) suhu optimum bagi pertumbuhan Chlorella sp adalah antara 25-30 ${ }^{\circ} \mathrm{C}$. Untuk kultur Chlorella sp diperlukan suhu antara 25-35 ${ }^{\circ} \mathrm{C}$ sesuai menurut Raymont dalam Sidabutar (2016) bahwa suhu optimum untuk pertumbuhan fitoplankton adalah 25-32 ${ }^{\circ} \mathrm{C}$. Rata-rata perubahan suhu pada tiap perlakuan selama penelitian berlangsung tidak jauh berbeda.

\section{pH}

Pada setiap perlakuan sangat mendukung untuk pertumbuhan mikroalga Chlorella sp. Karena rata-rata nilai $\mathrm{pH}$ yang diperoleh pada kisaran 5-8. Menurut Kaswadji dalam Sidabutar (2016) nilai $\mathrm{pH}$ untuk pertumbuhan Chlorella sp berkisar 7,2-8,5. Semakin tinggi konsentrasi limbah pupuk cair yang diberikan pada media kultur, umumnya pH pada media kulturpun ikut meningkat.

Hal ini disebabkan oleh tingginya kandungan bahan mineral yang ada pada Pupuk Organik Cair, karena alkalinitas atau jumlah basa yang terkandung badan air biasanya berkaitan dengan kesadahan air dimana faktor yang membuat kesadahan air tinggi adalah kandungan garam-garam mineral di dalam perairan, seperti $\mathrm{Mg}, \mathrm{Cu}, \mathrm{Ca}$, dan $\mathrm{Fe}$ (Effendi, 2003).

\section{Nitrat $\left(\mathrm{NO}_{3}\right)$}

Kandungan nitrat pada hari ke-0 (sebelum kultur Chlorella sp) bahwa kandungan nitrat semua mengalami kesamaan hasil data yang di peroleh pada perlakuan. Hal ini sesuai dengan pendapat Lubis dalam Sugianti (2016) yang menyatakan bahwa semakin tinggi konsentrasi larutan dan semakin rendahnya konsentrasi kandungan nitrat yang dihasilkan tidak termanfaatkan secara baik, maka jumlah unsur hara yang terkandung juga semakin besar tetapi tidak termanfaatkan.

Tabel 2. Nitrat $\left(\mathrm{NO}_{3}\right)$

\begin{tabular}{cccl}
\hline Perlakuan & Awal & Akhir & Total \\
\hline P1 & 4,92 & 13,22 & $-8,3$ \\
P2 & 4,92 & 27,11 & $-22,19$ \\
P3 & 4,92 & 25,99 & $-21,07$ \\
P4 & 4,92 & 19,84 & $-14,92$ \\
P5 & 4,92 & 14,93 & $-10,01$ \\
\hline
\end{tabular}

Pada penelitian yang dilakukan Yolanda dalam Sugianti (2016) mendapatkan konsentrasi nitrat yang relatif lebih tinggi yaitu mencapai 18,4 mg/L. Perbedaan ini diduga dipengaruhi oleh proses pengolahan Pupuk Organik Cair, yang dihasilkan belum diproses secara aerobik sehingga konsentrasi $\mathrm{N}$ pada limbah cair masih tergolong tinggi. Dari Gambar 7. dapat diketahui bahwa pada setiap perlakuan terjadi penurunan kandungan nitrat. Turunnya konsentrasi nitrat pada tiap perlakuan dikarenakan adanya tidak termanfaatkan jumlah unsur hara yang terkandung dalam pupuk organik cair untuk pertumbuhan Chlorella sp, di mana nutrien yang paling dibutuhkan fitoplankton bagi pertumbuhannya adalah nitrogen dalam bentuk nitrat (Nybakken dalam Vitriani 2016).

Oleh sebab itu, semakin padat jumlah sel Chlorella sp, maka semakin banyak pula unsur hara yang tidak termanfaatkan hal ini dikarenakan adanya penuruanan pada kelimpahan Chlorella sp. Apabila kondisi media kultur kekurangan nitrogen, maka proses fotosintesis menjadi terhambat. Ketika proses fotosintesis terhambat, maka energi yang dibutuhkan menjadi sedikit, sehingga 
dapat menyebabkan pertumbuhan mikroalga menjadi tidak optimal.

\section{Posfat $\left(\mathrm{PO}_{4}\right)$}

Dapat diketahui bahwa kandungan posfat tertinggi pada akhir penelitian yaitu P5 dan terendah pada P4. Kandungan posfat pada tiap perlakuan telah memenuhi syarat untuk pertumbuhan Chlorella sp, karena nilai posfat yang optimum untuk kehidupan mikroalga adalah 0,018-27,8 mg/l (Mas'ud , 2016).

Tabel 3. Posfat $\left(\mathrm{PO}_{4}\right)$

\begin{tabular}{crrr}
\hline Perlakuan & \multicolumn{1}{c}{ Awal } & \multicolumn{1}{c}{ Akhir } & \multicolumn{1}{c}{ Total } \\
\hline P1 & 0,992 & 0,3505 & 0,6415 \\
P2 & 0,992 & 0,4484 & 0,5436 \\
P3 & 0,992 & 0,338 & 0,654 \\
P4 & 0,992 & 0,134 & 0,858 \\
P5 & 0,992 & 0,2436 & 0,7484 \\
\hline
\end{tabular}

Berbeda dengan nitrat yang lebih rendah jika dibandingkan dengan hasil penelitian Vitriani (2016) fosfat pada penelitian ini justru lebih tinggi dengan konsentrasi fosfat pada Pupuk Organik Cair maka dapat diketahui, dengan perlakuan jenis Pupuk Organik Cair kompos yang berbeda, maka kandungan nutrien yang ada pada Pupuk berbeda pula.

\section{Kalium (K)}

Dapat diketahui bahwa kandungan kalium pada awal dan akhir penelitian tidak termanfaatkan dengan baik oleh Chlorella sp. Hal ini disebabkan karena Chlorella $s p$. tumbuh sudah mengalami penurunan pada perlakuanya sehingga unsur hara atau pupuk tambahan yang diberikan sudah tidak digunakan lagi oleh sebab itu hanya sebagai amonia saja. POC mempunyai peluang sebagai pupuk media alternatif untuk menumbuhkan mikroalga karena mengandung bahan anorganik seperti nitrogen, fosfor dan kalium.

Tabel 4. Kalium (K)

\begin{tabular}{cccc}
\hline Perlakuan & Awal & Akhir & Total \\
\hline P1 & $-1,9746$ & $-1,9054$ & $-0,0692$ \\
P2 & $-1,9746$ & $-1,9054$ & $-0,0692$ \\
P3 & $-1,9746$ & $-1,9054$ & $-0,0692$ \\
P4 & $-1,9746$ & $-1,9054$ & $-0,0692$ \\
P5 & $-1,9746$ & $-1,9054$ & $-0,0692$ \\
\hline
\end{tabular}

Bahan anorganik ini berasal dari bahan organik seperti protein, kabohidrat, lemak. Bahan organik tersebut dapat terdegradasi dan teroksidasi menjadi bahan anorganik (Effendi, 2003). Isnansetyo (1995) menyatakan bahwa kalium berfungsi dalam metabolisme karbohidrat dan juga sebagai kofaktor untuk beberapa koenzim.

\section{KESIMPULAN DAN SARAN}

\section{Kesimpulan}

Dari penelitian yang telah dilakukan dengan pemberian Pupuk Organik Cair (POC) dengan rentang waktu yang berbeda terhadap kelimpahan Chlorella sp maka dapat disimpulkan bahwa:

1. Penggunaan Pupuk Organik Cair (POC) dengan rentang waktu yang berbeda memberikan pengaruh yang terhadap kelimpahan Chlorella sp dengan kelimpahan tertinggi sebanyak 9.833.333 $\mathrm{sel} / \mathrm{ml}$ pada perlakuan P3, sedangkan kelimpahan yang terendah terdapat pada perlakuan P1 yaitu sebesar 2.566.667 $\mathrm{sel} / \mathrm{ml}$.

2. Puncak populasi kelimpahan Chlorella terjadi bervariasi yaitu pada hari yang berbeda. Untuk perlakuan P1 puncak terjadi pada hari ke-12, perlakuan P2, P3 dan P4 dan P5 terjadi pada hari ke-5.

3. Kualitas air yang diperoleh dengan suhu berkisar $29-30^{\circ} \mathrm{C}$, hasil rerata nilai $\mathrm{pH}$ berkisar 5-8, pemanfaatan $\mathrm{N}, \mathrm{P}, \mathrm{K}$ berturutturut pada perlakuan yang tertinggi yaitu $21,07 \mathrm{mg} / \mathrm{L}, 0,654 \mathrm{ppm},-0,0692 \mathrm{ppm}$.

\section{Saran}

Dari kesimpulan di atas maka diperoleh beberapa saran terhadap penerapan yang digunakan dan juga kelanjutan penelitian yang akan dilakukan kedepannya. Untuk pengaplikasian menggunakan POC dengan rentang waktu dapat dilakukan penambahan pupuk susulan pada hari ke-7. Sedangkan penelitian lanjutan yang akan dilakukan dengan cara fermentasi untuk menambahkan bakteri yang dapat meningkatkan pertambahan populasi pada Chlorella sp.

\section{DAFTAR PUSTAKA}

Becker, E. W. 1994. Microalgae Biotechnology and Microbiology. Cambridge University Press, Melbourne.

Cahyo A. D. 2011. Teknik Kultur Skeletonema costatum Sebagai Pakan Alami Udang Vaname. Balai Besar Pengembangan Budidaya Air Payau Jepara Jawa Tengah. Fakultas Perikanan dan Kelautan Unair, Surabaya. 
Djarijah, A. S. 1995. Pakan Ikan Alami. Kanisius, Yogyakarta.

Effendi, H. 2003. Telaah Kualitas Air bagi Pengelolaan Sumber Daya. Kanisius, Yogyakarta.

Fadilla, Z. 2010. Pengaruh Konsentrasi Limbah Cair Tahu terhadap Pertumbuhan Mikroalga Scenedesmus sp. Skripsi (Tidak Dipublikasikan). Fakultas Sains dan Teknologi, Universitas Islam Negeri Syarif Hidayatullah, Jakarta.

Isnansetyo, A dan Kurniastuty. 1995. Teknik Kultur Phytoplankton dan Zooplankton: Pakan Alami untuk Pembenihan Organisme Laut. Cetakan Pertama. Kanisius, Yogyakarta.

Nur, M. 2018. Pemberian Pupuk Organik Cair (POC) dengan Dosis Berbeda untuk Pertumbuhan Chlorella sp. Skripsi (Tidak Dipublikasikan). Prodi Budidaya Perairan, Fakultas Pertanian, Universitas Islam Riau, Pekanbaru.

Prabowo, D. A. 2009. Optimlisasi Pengembangan Media untuk Pertumbuhan Chlorella sp pada Skala Laboratorium. Skripsi (Tidak Dipublikasikan). Program Studi Ilmu dan Teknologi Kelautan, Fakultas Perikanan dan Kelautan, Institut Pertanian Bogor, Bogor.

Sidabutar, H. 2016. Pemanfaatan Limbah Cair Industri Tahu untuk Pertumbuhan Mikroalga (Chlorella sp.). Skripsi (Tidak Dipublikasikan). Fakultas Perikanan dan Ilmu Kelautan, Universitas Riau, Pekanbaru.

Vitriani, F. N. 2016. Pengaruh Pemberian Limbah Cair Kelapa Sawit terhadap Pertumbuhan Mikroalga Chlorella sp. pada Ruang Terbuka. Skripsi (Tidak Dipublikasikan). Fakultas Perikanan dan Ilmu Kelautan, Universitas Riau, Pekanbaru. 
